\title{
Productive Bodies, Docile Women and Violence
}

\section{Exploring 'Respectable Work' as Physical Abuse within Ireland's Magdalene Laundries}

Chlö̈ K. Gott | ORCID: 0000-0002-9988-8120

Department of Religious Studies, King's College London, London, UK chloe.k.gott@gmail.com

\begin{abstract}
Drawing on the Government of Ireland Collaborative Research Project, 'Magdalene Institutions: Recording an Archival and Oral History', this paper explores the nature of women's experiences in Ireland's Magdalene laundries though the lens of forced work. I argue that the perceived nature of the work done by the women-productive, respectable, 'women's work'-significantly impacted on how the abusive nature of the laundries has been considered by official bodies and wider Irish society. This paper focuses on work done in these institutions and how it was viewed, using interviews from survivors and those who visited the laundries. By exploring the links between work and respectability, productivity and morality, with particular attention to the ways this plays out upon the bodies of women, this article argues for an understanding of this work as a violent and disciplinary process, designed to produce the desired Irish Catholic female body: docile and productive, penitential and obedient.
\end{abstract}

\section{Keywords}

Magdalene laundries - oral history - forced labour - women - trauma respectability - productivity

In June 2018, I volunteered at Dublin Honours Magdalenes, a two-day event to commemorate survivors of Ireland's Magdalene laundries. The women attending this event had all spent time in the one of the ten Magdalene institutions 
which existed in twentieth-century Ireland, run by one of four Catholic orders. These were carceral religious spaces, part of Ireland's architecture of containment (Smith 2007) where women who were "most threatening to establishment sensibilities" (McGettrick et al. 2021, 13) could be contained and punished. Whilst there is a general assumption that most women were sent here for the 'sin' of having a child outside of marriage, survivor testimony suggests that this was only true for a minority of cases. Mostly, women incarcerated within these institutions were young and poor, and were often victims of abuse and domestic violence, guilty of "being in the way" (Smith 2007, xiii). Women could be sent to a laundry by their family, by a priest, or via social services; spending anything from a few months to their whole lives there, washing clothes with no information about whether they would leave. The last of these institutions closed in 1996, but it was not until 2013 that the Irish State apologised for their role in this system, and the religious orders who ran the laundries have yet to issue a formal apology or contribute to a financial redress scheme.

Over 200 women travelled to Dublin for the event, which included a visit to Áras an Uachtaráin ${ }^{1}$ for a reception and speech by the President of Ireland, Michael D. Higgins; a formal dinner in Dublin; and a listening exercise designed to give women space to talk about their experiences. The event was a memorable one, and I feel deeply privileged to have taken part. For many women, it was a significant and important step in the process of redress and commemoration which had previously been denied to them. However, I wish to draw out one small detail which, for me, was emblematic of a wider social issue which lingers on in discussions of the Magdalene institutions. On the first day of the event, the women were invited to Áras an Uachtaráin. Upon arrival, we were escorted through the house and towards a grand marquee in the garden. I picked up the programme for the day and as I read it, I hesitated over the wording chosen to introduce the event:

President Michael D. Higgins and his wife Sabina Higgins welcome former workers of the Magdalene laundries to a reception in Áras an Uachtaráin, Tuesday 5 th June 2018

The booklet was a beautiful object, and it gave the women something to take home from the event, to remember the experience by. It also gave the event a sense of importance - the heavy white card and detailed programme imbu-

1 Áras an Uachtaráin, formerly the Viceregal Lodge, is the official residence and principal workplace of the President of Ireland. 
ing the proceedings with ceremony. Several women I spoke to made efforts to ensure they had one before leaving; I gave mine away to someone who had misplaced hers and did not want to leave without one.

It is clear that for many women the booklet was a valuable and positive object, making them feel valued and important. However, the description of the survivors as 'former workers' frames the Magdalene institutions in a very particular way, namely as places of work. This heavy emphasis on the labour performed by the women during their time in the laundries, with no acknowledgment of the non-consensual conditions in which this labour was done, obscures the reality of the institutions. It frames the women as workers, as productive members of the nation's past, rather than survivors of state-sanctioned institutional abuse. Referring to victims of institutional trauma as 'former workers' is a subtle rewriting of the narrative around what the Magdalene laundries were-here, they exist as sites of labour, rather than of trauma and violence.

In highlighting this, I do not mean to suggest this was necessarily a deliberate obfuscation by the organisers of this part of the weekend, and indeed there are many reasons why it may have been the appropriate wording for the occasion. However, it is not an isolated incident. As I will demonstrate in this article, there are many examples of the institutions being conceptualised in this way, by the Irish State as well as by wider society. However, in thinking of the labour done by the women who were incarcerated in these spaces, it is important to remember that it was forced labour. They were not given a choice, and in almost all instances, were not compensated for their work. Forced labour as a form of punishment has a long history, and has been used globally, in many forms. This type of work is also frequently overlaid with moral meanings - it is intended to give value to those who do it, giving them a sense of 'purpose' and rehabilitating them as productive members of society. It is this type of 'productive' forced labour, and the moral meanings it is saturated with, that this article explores.

Drawing on the Government of Ireland Collaborative Research Project, 'Magdalene Institutions: Recording an Archival and Oral History', this paper will focus on the nature of women's experiences in Magdalene institutions through the lens of forced work. I argue that the perceived nature of the work required by the women-productive, respectable, 'women's work'-significantly impacted on how the violent nature of the laundries has been considered by official bodies and wider Irish society. After giving a brief introduction to the Magdalene laundries in Ireland, I will discuss the links between productivity and religious morality, paying close attention to the ways these are enacted upon the bodies of women. I then move on to a more detailed description of the oral history archive and how I engaged with this resource. I will then 
consider the work done by the women in the institutions, moving away from describing it as labour towards an understanding of it as a disciplinary process and a form of violence. Finally, I draw on interviews taken with key informants to show how they primarily describe the work as productive labour, rather than violence. Throughout the paper, I argue for an understanding of work in the laundries as a form of violent punishment, sanctioned through religious power. In this way, the violent nature of the work can be reframed as 'productive' because it acts as a moral balance to the perceived sins of the Magdalene women. They were seen to be sinners, outside the confines of womanhood as defined by the Catholic Church and Irish State, and therefore the forced labour of the laundry work was a form of bodily penance through 'moral acts'. This rests on the underlying religious assumption that to do penance for sin, we must often endure some form of pain (Glucklich 2001). Duff (2003) defines penance as something necessarily painful or burdensome which is done to alleviate sin, emphasising that "this is part of its point or meaning: a wouldbe penance that was not painful or burdensome would for just that reason be defective as a penance" $(2003,299)$. This link between doing penance and enduring pain, whether bodily or psychic, therefore makes it possible for the laundries to be reimagined by some as sites of penitence and productive work where women could make amends — rather than sites of violence and trauma.

The last Magdalene laundry in Ireland closed its doors in 1996, but institutions of this nature have existed in some form since the late eighteenth century. Developing out of the eighteenth-century rescue movement designed to control the perceived threat of increased prostitution (O'Mahoney 2018, 456), by the twentieth century they formed part of a broader institutional response to 'problem women' - women who transgressed social boundaries of postIndependence Ireland. Most of the written history of the laundries in Ireland is focused on the nineteenth century, primarily because the religious orders who ran the institutions have, to date, kept their archival records from the twentieth century closed to researchers and survivors. ${ }^{2}$

2 They were made available to the State in 2013 , but since then have remained inaccessible to those seeking to learn more about the lives of the women who were incarcerated there. In 2018, the Department of Justice told UNCAT that they had no power the compel religious orders to make these accessible, but this is contested by scholars and activists (McGettrick et al. 2021, 139). 
Although we know less about how the laundries functioned in the twentieth century, most writers on the subject (e.g., McGettrick et al. 2021; O'Mahoney 2018; Fischer 2017; Crowley and Kitchen 2008; Smith 2007) agree that there was a significant shift in the nature of these institutions in post-Independence Ireland, towards a more carceral and punitive model. The institutions became a place to send women who threatened the 'moral fabric' of the newly formed Catholic Irish State (Fischer 2017), including women who committed petty crime, women who had grown up in the industrial school system and were deemed 'at risk' of falling into sin, women who had children outside of marriage, or women who made accusations of abuse towards older male family members. Typically, women could be sent to a laundry by their family, by a priest, or via social services. They spent anything from a few months to their whole lives in these institutions, washing and sorting laundry without receiving wages, almost always with no information about how long they were to spend there. Whilst all of the women who took part in the oral history project left the institutions after a period of incarceration, many women did not, and died in the laundries. ${ }^{3}$ Following the closure of the laundries, some women remain in the care of the religious orders, in religiously run nursing homes (McGettrick et al. 2021, 151).

\section{Respectable Work and Good Women}

This article argues that one of the reasons the work done in Magdalene institutions was frequently not considered to be a form of physical violence, by either the State or members of the wider society, is due to the moral value ascribed to productivity in contemporary society. 'Work', and in particular productive labour, has been considered a measure of morality for centuries (Halasz 2012) - we are encouraged from a young age to get a job, to contribute to and be productive members of society. Work provides many people with a sense of identity - one of the first questions we ask people when we meet them often is, 'So, what do you do?' In the following section, I will explore the links between productivity and morality, before moving onto an exploration of the deeply

3 The experiences of women who left the laundries are diverse and complex-survivors draw on a range of social and religious processes to re-engage with their subjectivity following their departure from these spaces, and to manage the feelings of shame and terror which their time in the laundries created. These experiences are explored in greater detail in the forthcoming monograph, 'Experience, Identity \& Epistemic Injustice Within Ireland's Magdalene Laundries' (Gott forthcoming). 
gendered ways this plays out in the discourse around 'bad' women and unmarried mothers.

Early roots of this focus on productivity as a moral value can be found in Weber's exploration of the 'Protestant work ethic' (Weber 2001 [1930]), the idea that just as priests and caring professionals are deemed to have a vocation (or "calling" from God) for their work, 'the lowly workman' also has a noble vocation which he can fulfil through dedication to his work. Just (2017) emphasises how "against the medieval view of work as unavoidable necessity, and hence something not to be praised in itself, Protestants introduced work as a virtue and waste of time as a deadly sin" (Just 2017, 2). He goes on to stress that this idea of "work as God's calling, a commandment to work for the divine glory with an ever-increasing success" (Just 2017, 3) has far-reaching social and psychological consequences for modernity. As Barrington Moore highlights, in the nineteenth century working regularly and scrupulously was still the keystone of a lifestyle that was deemed moral, and thus good, because it was rational and methodical (Moore 1998, 39).

However, the idea of work as a moral virtue is not limited to the Protestant faith. Some writers suggest that this cultural appreciation of hard work and thrift had pre-Reformation origins in the Catholic Order of Cistercians, who encouraged economic growth in Europe during the second millennium by instigating the kind of cultural change in local populations that Weber attributed to Protestantism (Anderson et al. 2017). This attitude towards work also is present in more recent Catholic teaching. In an article on the concept of a Catholic work ethic, $\operatorname{Höpfl}(2007,399)$ quotes from John Paul II's Laborem Exercens, which describes work as "a fundamental dimension of human existence" (John Paul II 1981), and as "a good thing for man-a good thing for his humanity-because through work man not only transforms nature, adapting it to his own needs, but he also achieves fulfilment as a human being and indeed, in a sense, becomes 'more of a human being'” (John Paul II 1981).

'Working hard' has long been triumphed as a way for people to find meaning and value in their lives. From the ghoulish 'Arbeit Macht Frei' above the gates of Auschwitz-which itself comes from the title of an 1873 novel by German philologist Lorenz Diefenbach, Arbeit macht frei: Erzählung von Lorenz Diefenbach, in which gamblers and fraudsters find the path to virtue through labour-to Iain Duncan Smith's statement in 2010 on ввС Breakfast that "Look, work actually helps free people", we are repeatedly told that it is only by working hard that we become a productive and valued member of society. It is also through hard work that we regulate ourselves-the collective idea that to be respectable, one must have a job and submit to a certain set of societal expectations around that means that we are frequently locked into systems of 
self-regulation and monitoring, producing ourselves as governable subjects in an attempt to gain respectability (Skeggs 1997, 162). This is especially true for those whose bodies are viewed by society as inherently lacking in respectability; for example, working class people, women, people of colour. For these groups, hard work is often promoted as the only way to prove themselves as respectable, productive social agents - and yet they must work far harder to do so than someone occupying a place of greater social privilege (DeSante 2013).

As a result of these strong historical and contemporary links between productivity and morality, stigma against those who do not or cannot work is extremely prevalent - people who for whatever reason are not engaged in this productive labour are conceptualised as immoral, undeserving and sinful. Sennett (1998) argues that it was in the mid-nineteenth century that the moral value of work and of being self-sufficient, and the consequent fear of being unproductive and dependent, became ingrained in society. The historical distinctions between 'deserving poor' - those who worked hard, kept their homes and families clean, went to church regularly, did not spend money on drink, and otherwise adhered to middle-class morals; and 'undeserving poor' - those who had earned their poverty not only by refusing to work, or to work hard enough, but also by rejecting the middle-class model-are reproduced in contemporary discourse regarding 'benefits cheats', 'strivers vs skivers', and 'welfare queens'. As George Orwell writes, "every middle-class person has a dormant class prejudice which needs only a small thing to arouse it ... The notion that the working-class have been absurdly pampered, hopelessly demoralised by dole, old-age pensions, free education etc." (Orwell 2001, 123-124). Valentine and Harris (2014), in an article on the moral dimensions of class prejudice, emphasise that this prejudice "was evident amongst the participants for whom moral worth was frequently predicated on a willingness, and capacity, to undertake paid work-in other words on economic value" (Valentine and Harris 2014, 87 ). As a result, those who do not or cannot engage in paid employment are characterised as "socially and morally separate from, and a drag upon, the hardworking majority population" (Valentine and Harris 2014, 87), an idea which has become firmly rooted in public discourse.

In the context of the laundries, these links between productivity, work and morality take on specific gendered and religious dimensions. As they washed and sorted laundry, women were considered to be doing penance-literally washing away their sins, cleansing their souls through hard work which not only gave them a purpose, but had a materially productive outcome-clean laundry; and a morally productive one-a cleansed soul. Women who had previously posed a threat to the moral fabric of society were now not only confined for the public good, preventing them from causing harm to others; but they 
could also make amends for their sins by physically cleaning dirt, doing good for their communities. They were working hard, but they were also doing 'women's work'-productive and reproductive labour, which would benefit society as a whole, and equip them with skills to become good wives and mothers, helping maintain the heterosexual family which was at the heart of the Irish State in the twentieth century. The gendered dimensions of this must be understood with reference to the long history of women's bodies being used as markers for the moral boundaries of a state (McClintock 1997, Kandiyoti 1991). Through the control of 'their' women's behaviour, nations can separate themselves from others. Therefore, women become a "special focus of state concerns as a social category with a specific role (particularly human reproduction)" (Anthias and Yuval-Davis 1989: 6). This 'specific role' of women in the state means that they are allocated what Yuval-Davis (1997) describes as a "burden of representation", resulting in the development of specific codes and regulations, defining who and what constitutes a 'proper man' and a 'proper woman', which are central to the moral identities of the nation and its members (Yuval-Davis 1997: 67).

The gendered dimensions of discourse around productivity and morality are particularly evident when thinking about single mothers. Unmarried mothers have had a long history of stigma in the UK and Ireland (Thane and Evans 2013; Earner-Byrne 2007), and whilst this stigma has shifted in the last fifty years, it is far from eradicated. For example, an article by Melanie Phillips in 2011 in The Daily Mail on the breakdown of families states that the combination of the sexual revolution, the Pill and the welfare state saw women being told that "sex outside marriage was fine, unmarried motherhood was fine-and crucially, that the welfare state would provide them with the means to live without male support" (Phillips 2011). She goes on to emphasises that "this whole process [of family breakdown] is driven by women and girls", as a direct result of the welfare state. If it is to be remedied, she writes, "women and girls have to come to a different conclusion about where their interests lie. That means the welfare state has to stop playing the role of surrogate husband through the benefits it gives single mothers" (Phillips 2011).

Whilst it is clear that Phillips' or The Daily Mail's views are not representative of all wider social attitudes, articles such as this, and the rise in voyeuristic media focusing on 'single mums on benefits', show that stigma towards lone parents is still apparent. However, this stigma is now sharply classed-Phillips is not simply attacking lone parents, she directs her column specifically to those on benefits. In the twenty-first century, when the social stigma of single motherhood has lifted somewhat, it is primarily within a class analysis that it lingers. A combination of classism and misogyny produce single mothers claiming benefits as lazy, immoral and a drain on society. This attitude can be seen in Irish 
media as well. An anonymous article from The Irish Times in 1996 (the year in which the last Magdalene institution closed) states:

It seems to me we've gone from one extreme to the other in the space of 20 years, from one of complete intolerance towards single mothers to completely unquestioning acceptance. And I think it's time we asked a few questions.

Rise and Rise of the Welfare Mother, 1996

The author is clear to differentiate between lone parents who claim welfare and those who do not, and it is the former group who are presented as the problem, a threat to themselves and society.

The Magdalene institutions have a strong association with unwed mothers, and many believe that this was the primary demographic incarcerated there. From the interviews in the oral history archive, this does not seem to be the case. However, it is undeniable that the stigma of lazy, unproductive mothers is interwoven with the stigma experienced by Magdalene survivors - and therefore it is unsurprising that their penance should involve hard work, shaping them into good, penitent Irish Catholic women.

\section{4 'Magdalene Institutions: Recording an Archival and Oral History'}

With these links between religion, gender, productivity and morality in mind, I now turn to the primary resource upon which this article is based. Although a growing literature on the Magdalene institutions has developed over the past twenty years, across a range of disciplinary approaches (e.g., McGettrick et al. 2021; O'Mahoney 2018; Clough 2017; Fischer 2017; Crowley and Kitchen 2008; Smith 2007; Luddy 2007; Finnegan 2001), this work has primarily focused on describing or situating these institutions in wider historical, cultural, and religious contexts, with less attention paid to women incarcerated in these institutions as producers of knowledge on their own experiences. In part, this has been due to a lack of resources focused on survivor narratives, and so to address this, an oral history project was conducted. 'Magdalene Institutions: Recording an Archival and Oral History' was a Government of Ireland Collaborative Research Project, funded by the Irish Research Council. ${ }^{4}$ The overall

4 More information on the oral history project is available here: http://jfmresearch.com/home/ oralhistoryproject/. 
objective of this study was to contribute towards a better understanding of the Magdalene laundry system that existed in Ireland through interviews with survivors and their family members, as well as visitors to those institutions and other key informants. Key informants referred to people who had some involvement in or interaction with the laundries, such as a doctor and a maintenance worker.

This project forms the basis of this article. I draw on interviews from survivors and key informants to explore how work and violence are discussed by those who experienced it. I also draw on other material, such as statements and reports from government officials and committees. The oral history archive is gradually being made available online, but as part of my doctoral work, I was given access to the whole archive; eighty-one interviews in total. Of these, thirty-nine were taken from survivors, twenty-one from key informants, fourteen from relatives, three from activists and three from people designated as 'other'. When researching this article, I used both transcripts and audio recordings of these interviews, as not all the interviews had been transcribed when I started the process of analysis. Because of the nature of the two forms of resource, my referencing style necessarily changes when quoting from a transcript or an audio file. For transcripts, I use the interview reference code and page number (for example, MAGOH P/4/ANON, Mary: 24). For audio files, I reference the timestamp when the quote begins (for example MAG OHP/o6, Patricia Dervan: tape 6, oo:o9). For some interviews, there are multiple audio files, and I have made this clear by referring to tape 1,2 , etc., as in the previous example.

Since the research for this article involved secondary analysis of interviews which had already been conducted, issues of informed consent and avoidance of harm in the interview process itself did not manifest in the same way they would have done had I been conducting the interviews myself. Everyone who participated in the oral history project had consented to the interview process, and had also consented to have their words put in the public domain, to an agreed upon extent. Most interviewees use pseudonyms, although some chose to use their real names.

I now turn to my analysis of these interviews, in particular those which discuss the work done by women in the laundries. Paying close attention to the links between productivity and morality, I move away from the conceptualisation of this as 'work', and towards an understanding of this as bodily discipline, and 
specifically, a violent bodily punishment. In describing it as such, I situate my understanding of violence within a feminist framework of gendered violence, which as Frazer and Hutchings highlight has "emphasised the importance of grasping the implications of gendered violence from the standpoint of women experiencing it" $(2019,2)$ broadening out understandings of violence's controlling and destructive effects, beyond the specific physical damage inflicted (e.g., Kelly 1988; Lundgren 1998). Feminist research has helped create an understanding of structural violence as "the system of patriarchal domination of men over women, masculine over feminine, that produces and legitimates gendered violence" (Frazer and Hutchings 2019, 3). However, when considering the violence done to Magdalene survivors, it is vital to consider this within a religious framework, as well as within gendered social structures. Women sent to the laundries were being punished not just for being women, but for being the 'wrong' kind of woman, as conceptualised by the newly formed Irish nation. They were threatening the narrow conception of 'good' womanhood which was defined to a significant extent by the Catholic Church (Earner-Byrne 2007), sanctioned by a heterosexual Catholic marriage.

The most common form of work done by those in Magdalene institutions was laundry. This included pressing clothes, filling and emptying washing machines, and cleaning soiled nappies. This work is frequently described by interviewees as extremely tiring; many women speak about working six days a week, the hours were long, and the food not sufficient to sustain this level of physical exertion. Pippa Flanagan describes her first day in the laundry:

Now, my first day was in the laundry room sorting out the clothes and I was very sick because with the way the ... all the white coats and brown coats, and they were covered with blood and that ... we had no protection for our hands, no nothing, we had to lift the dirty clothes up and sew them ... So we were at that from about six o'clock in the morning and then we ... I was in the laundry then in the afternoon and it was back-breaking, completely back-breaking.

o'Donnell, K., PEMbroke, S. and MCGetTrick, C., 'An Oral History of Pippa Flanagan', MAGOHP/46/ANON, 2O13: 2

There are similar descriptions throughout the interviews-the work the women were forced to do was hard, painful and physically demanding. They report injury from the machines, inadequate medical care, and long-lasting physical health issues as a result of their time in the institutions. Speaking about meeting Magdalene survivors, Judy Campbell, an adoption rights activist says: 
First thing I notice about them was, they were about my age, maybe some were older, some were younger, but the first thing that struck me, I felt so sorry for them, was they had walking sticks, walking frames, and some were in wheelchairs, and I think they were crippled with arthritis ... there was I, the same age, no problems at all.

o'DonNell, K., PEMbroke, s. and MCGetTrick, C., 'An Oral History of Judy

Campbell', MAGOHP/O5, 2013: 26:44)

Evelyn, who was sent to a laundry in 1967 , aged 14, and was there for a year, is asked:

SP Okay. And did you get any physical or long-lasting health effects from ... from the laundry?

E Physical would probably ... probably be my hands, because my hands hurt now and from those big heavy irons that you've got in there. And then we used to have to scrub floors as well, and get on your hands and knees and scrub floors as well, and there was stone floors. So I'm assuming maybe it was that ... that's why my knees play up and that's why my hands play up.

O'DONNELL, K., PEMbroke, s. and MCGetTrick, C., 'An Oral History of Evelyn', MAGOHP/10/ANON, 2013: 56 [hereafter MAGOHP/10/ANON, Evelyn]

Throughout the interviews, references like this are common, with many survivors detailing significant long-term physical health issues stemming from their time in the laundries and the work they had to do.

With these testimonies in mind, I now turn to a different source which discusses physical abuse within the Magdalene institutions. In June 2011, the Irish government announced the creation of 'The Inter-Departmental Committee to establish the facts of State involvement with the Magdalen Laundries' (IDC). After an eighteen-month inquiry, the IDC published a report in February 2013, commonly known as the McAleese report. The report concluded that there had been significant state involvement in the Magdalene institutions. Whilst this was undoubtedly an important event in the timeline of the Magdalene institutions, the report has been critiqued by survivors, activists and human rights organisations (e.g., McGettrick et al. 2021; O’Rourke et al. 2017; McGettrick et al. 2015; Irish Human Rights and Equality Commission 2015), who feel that the process of the Committee, and the final report, was not an accurate representation of experiences as told by the women who gave testimony. An example of this can be seen in Chapter 19, which sets out to examine living and working conditions in the laundry, stating that "although this Chapter identifies a 
number of patterns among the stories shared with it, the Committee did not make specific findings in relation to this issue [of living and working conditions], in light of the small sample of women available" (McAleese 2013, 925). However, the report does make a point to stress the lack of physical abuse in the Magdalene institutions, as opposed to the industrial schools, where physical beatings were far more frequent, stating that "a large majority of the women who shared their stories with the Committee said that they had neither experienced nor seen other girls or women suffer physical abuse in the Magdalen Laundry" (McAleese 2013, 932).

There are two key points which are important to highlight when thinking about physical abuse and violence, and how this shaped the experiences of the women in the laundries. Firstly, it is necessary to highlight the factual inaccuracy of this statement. Even if we limit our conception of physical abuse to beatings, which I will later argue is an inadequate definition, many of the interviewees in the oral history project, both survivors and key informants, report that the nuns were frequently physically violent towards women. Trevor Heaney, a maintenance man employed in the Good Shepherd Laundry in Limerick in the mid-197os states:

There was one nun that used to be outside the workshop at the laundry, where my workshop was, and when she got angry she thought nothing of pulling the strap out. She pulled the strap out and hit them to get them to speed up-physically hitting. Now she was old school.

o'DonNell, K., PEMbroke, S. and MCgettrick, C., 'An Oral History of Trevor Heaney', MAGOHP/61, 2010: 5

He describes the nun as 'old school', perhaps implying that her behaviour was not the norm during his time in the laundries, but suggesting that this had been acceptable behaviour previously. Mary O'Mara was a Girl Guide Leader for many years. Through this work she came in contact with children from the Good Shepherd orphanage, one of whom eventually came to live with her for a time. Speaking of the same institution as Heaney, she states:

And there was one nun - she was a serpent. She used to kill the 'in girls'. She used to just catch them by the back of the hair and turn them around and hit them across the back of the knuckles, right down across the back of the knuckles. You know those sticks, bamboos. You could be walking along and you'd get it across the back of the legs.

o'DONNELl, K., PEMBRoKe, s. and MCGETTRick, C., 'An Oral History of Mary

O'Mara', MAGOHP/64, 2010: 5 
Violence is also frequently described by the survivors themselves, often as punishment for minor perceived wrongdoings.

If you forgot ... lost a sock or something, you'd be beaten to a pulp for this because like you know, your job ... you had to do your job right and this was the job you had to do. If you did it wrong you ... you ... hell to pay ...

O'DONNELL, K., PEMBRoKe, S. and MCGETTRICK, C., 'An Oral History of Lucy', MAGOHP/O7/ANON, 2O13: 5

SP How you and the other women were disciplined and punished? E Well, if you can visualise a belt or a big cane, that's how we were punished. You'd get grabbed by the hair, dragged into the office to see the Mother Superior, and you'd have to explain yourself-there again you weren't always given a chance to explain yourself-and you'd get the cane across the backside, across the legs or the belt ...

MAGOHP/10/ANON, Evelyn: 27-28

These examples, amongst others, trouble the assertion made in the McAleese report regarding the frequency of physical abuse. This paper does not use quantitative analysis to determine what percentage of women experienced violence of this nature; indeed, such a task would be impossible unless one spoke to significantly more women than either the oral history project or the McAleese report have done, and so I cannot state with authority that either a majority or minority did or did not experience violence. However, regardless of the frequency of actual violence, what is clear is that violence was a feature of the laundries-it was a constant potential threat, an ever-present possibility. In this way, the fear of violence acts as a further disciplinary tool for those within, and therefore this form of potential violence, as well as the experiences of actual violence, would have significantly shaped the behaviour and experiences of those who spent time there.

Secondly, and I would argue more importantly, the idea that violence in the form of beatings is the only way women could have experienced physical abuse in the institutions is one which is deeply flawed; it fails to address the inherently violent nature of the laundries. Forcing women to work long hours, doing physically demanding manual labour, for no money, with a severely limited diet, should be considered violence in and of itself. You do not need to beat someone to inflict actual physical harm on them. As Patricia Dervan, a relative of a Magdalene survivor, highlights: 
She [her sister in law] never complained of physical abuse in the sense of being beaten or physically attacked, but of course there was physical abuse through starvation and over work etc.

o'Donnell, K., PEMbroke, s. and MCGetTrick, C., 'An Oral History of Patricia Dervan', MAGohp/o6, 2013: tape 2, 32:0о [hereafter MAGoнp/o6, Patricia Dervan]

Through the descriptions given by survivors of daily life in the laundries, of the routine, the punishments, and the slow erosion of their selves, we can see how the institutions served "to discipline the body, optimize its capabilities, extort its forces, increase its usefulness and docility, integrate it into systems of efficient and economic controls" (Foucault 1980, 139), with the aim of producing the desired female body, that of the penitent - a religious woman who not only recognized her sins but saw incarceration and hard work as the only way to be absolved. The work done in the Magdalene institutions undoubtedly had a material value for the nuns, in that it generated an income for them. ${ }^{5}$ The McAleese report details that they had State contracts, washing laundry from prisons, hospitals and other institutions. However, the focus of this article is not on the outcome, but the process itself. The work done in the laundries was a way of disciplining the bodies of 'unruly' women, forming them as productive, docile citizens. As such, I argue that conceptualising this work as productive labour, rather than punishment and physical violence, ignores the harsh realities endured by survivors of the Magdalene institutions.

\section{Public Perceptions of the Magdalene laundries}

I now wish to think further about the ways in which this was conceptualised as work, and by whom. As well as interviews with women who had been in Magdalene laundries, the oral history project conducted interviews with what they termed 'key informants'. These were people who were involved with the laundries in peripheral roles such as maintenance and ad-hoc help, coming in and out of the institutions rather than confined within. These interviews give

5 The income of the laundries remains a point of contestation - the McAleese report concludes that the Magdalen Laundries were operated on "a subsistence or close to break-even basis rather than on a commercial or highly profitable basis" (2013: 993), whilst Justice for Magdalene activists have suggested that this seems unlikely, given the existence of an unpaid workforce. Whilst it is beyond the scope of this article to address the financial aspect of the laundries in depth, in part because a lack of access to archival records and the continued silence of the religious orders on the subject makes this task very difficult, it is important to mention this when thinking about the work done within these institutions. 
an extremely valuable insight into how people external to the laundries experienced them, how they perceived them as social institutions, as well as the ways in which they speak about and conceptualise the women themselves. This frequently slipped into an infantilising and patronising tone, and is particularly evident in an interview with John Kennedy. Kennedy had a long connection with the Good Shepherds in Limerick. He visited his aunts who were Sisters in the Order in Limerick many times as a child, and in adulthood Kennedy managed the Good Shepherd Laundry from the mid-1970s. He eventually took over the business as a private enterprise in the 1980 os. Speaking about the work done by the women, he says:

So Fiona [pseudonym] had the job of opening the steam valve and the pump would go tchit, tchit, tchit [noise of pump] because you would exhaust the steam every time to allow the piston to go back up and down again, and she then had to manually check the water level to check the level didn't go too high because if the water level went too high you got water coming over in the steam and you got spots of water coming out in the form of boiling water on the clothes you were supposed to be ironing. That was Fiona's job. Fiona was a dear.

GLYNN, E., 'An Oral History of John Kennedy', MAGOHP/63, 2013: 24 [hereafter MAGOHP/63, John Kennedy]

It is perhaps useful to remember at this point that this work was being done by unpaid women, held against their will. In referring to Fiona as a 'dear', Kennedy speaks about her more as one would an elderly and beloved grandparent, rather than someone who, in all likelihood, had been incarcerated for most of her life. He later, in glowing terms, speaks about the 'work ethic' of the women, saying:

If I had to separate those clothes for a week I'd have a biceps like a weightlifter from pulling and these poor women had to pull these clothes apart so you could feed them into an ironing machine. I still think they were marvellous women to do the type of work they did, backbreaking work some of it. And they did it without a murmur. A good example of their work ethic was a woman from County Tipperary who worked in the Wash Room. She would be in that laundry before her breakfast to have the machines loaded and started so there would be work ready for the driers and ironing machines when the rest of the women started after their breakfast. You know that is the way it worked. And there was nothing thought of it.

MAGOHP/63, John Kennedy, 2013: 27 
This positive focus on the 'work ethic' of people doing forced labour is jarring, and is a clear example of the ways in which the nature, as well as the quality and standard, of the work being done, allowed people to focus on the laundries as sites of labour, rather than sites of violence and trauma. Kennedy is speaking of these women as 'workers', and therefore judging them on the quality of their labour, despite knowing better than most that they were never paid for this labour. How has he managed to convince himself this? What does this tell us about the way that society values labour and productivity above personal autonomy?

Kennedy is not alone in using this kind of upbeat, positive tone when discussing the women in the laundries. It is apparent again in an interview with Dr M, who worked as a doctor in the Galway laundry in 1979, and then after it closed, until 1997. When asked whether his perception of the women in the laundries changed after working there, he answers:

Tremendously - in a pleasant way, I was pleasantly surprised, because I had conjured up this negative bleak image of them, and I was pleasantly surprised ... about how jovial they were, how jovial the surroundings were, how there was no obvious austerity in the system that I experienced.

o'donnell, K., Pembroke, S. and MCgettrick, C., 'An Oral History of Dr M', MAGOHP/1/ANON, 2O13: 56.04 [hereafter MAGOHP/1/ANON, Dr M]

Unfortunately, we have no survivor testimony from that particular laundry at that time with which to compare his experience. However, when reading the body of resources as a whole, there are few words which would spring to mind less than 'jovial', when describing the conditions of the laundries. When asked how he feels about the laundries now, he answered:

I feel cross if it's true, and some of the television presentations, some of the reader discussions about it are fairly convincing, that some injustice perhaps was done. One would like to put a balance on the nature of things, it is very important not to criticise 1950 with 2010 life, I think that's an important ... When I think back to times when girls, especially girls who had become pregnant or girls who had to escape from dysfunctional families, found refuge in these kinds of places, I suppose I'm still glad some refuge was there for them ... and yet, I'm cross that I'm given to believe that they were in some instances, not in all instances, treated and mistreated by individuals who perceived them as daughters of the devil, who had to be punished forever for their sins, and treated them unfairly, per- 
haps cruelly, because of that. I'm cross that we in society didn't detect that through the years, and do something about that.

MAGOHP/1/ANON, Dr M, 2013: 1:05:41

His phrasing regarding the abusive nature of the institutions-'fairly convincing', 'given to believe' - suggests that perhaps he is still not convinced, and needs more evidence from reliable sources. The underlying assertion to this passage is that we should not judge the past with values from the present. But the laundries were not something we can consign to 'the past'- they continued to exist well into the 199os, and the trauma suffered by the women who were incarcerated there continues into the present.

He later goes on to state that "all I can say is that I personally never became aware of something that I felt I should do something about" (MAGOHP/1/ANON, $\operatorname{Dr}$ M, 2013: 1:08:07). This statement is in reference to a question about physical abuse and violence. From this, and his previous statement, we can extrapolate that he did not see the hard work, forced labour or incarceration as problems, that the actual violence of locking women away was something he did not feel needed addressing.

This sentiment echoes that made by Sean Aylward in 2011, who at the time was Director General of the Department of Justice. Whilst answering questions from UnCAT Committee Members on human rights violations in the Magdalene Laundries, Aylward says:

I have personally met a deputation of women who had sad experiences to recount of their early childhood in these institutions. There is no doubt that they feel that the time they spent in the laundries had a scarring effect on their subsequent lives. The most serious allegations made by these women, and the organizations representing them, would if proven constitute criminal offences under Irish law. We have pointed this out to the groups representing these women. It has also been pointed out that there is no statute of limitations applicable to criminal offences in our jurisdiction. They have been invited to make complaints to our police force, the Garda Síochána, if they are aware of details of any possible offences, so they can be fully investigated under our criminal law. However, to the best of my knowledge, to date, they have not chosen to do this. These alleged events happened in most cases a considerable time ago in privately run institutions and therefore the information available to us is limited. However, as far as we can establish, on the facts available, the vast majority of women who went to these institutions, went there voluntarily, or if they were minors, with the consent of their parents or guardians. 
Again, the choice of wording here speaks volumes. These women have 'sad experiences', which they feel have had a scarring effect - we can assume Aylward perhaps feels differently. Because surely, if they were truly traumatised, they would have reported it to the police-since they have not, what other conclusions can be drawn? Aylward conveniently ignores, or is perhaps unaware of, the difficulties survivors of institutional abuse face when making accusations of this sort (Enright and Ring 2020), of the long history of Gardai involvement in returning women to institutions, of the continuing internalised stigma which made speaking out about any of their experiences painful and near impossible for so many women (Brownmiller 1975; Serisier 2018). For him, these events are 'alleged', part of a shadowy past which cannot be truly understood.

Of course, there has been movement in the approach taken by the State since 2011, as the Dublin Honours Magdalenes event demonstrated. However, there are threads of this which carry through much of the discourse, particularly the insistence on consigning the laundries to the past, to a different Ireland. Irish writer Anne Enright neatly catches the frustration caused by this mindset. Writing on the McAleese report, she says:

But, you know, it wasn't as bad as you might think. Many, many times longer than any woman's testimony is the testimony offered by Dr Coughlan, who seemed to have a splendid time in the Galway Laundry: 'After I sat down at my desk [name] a jovial Resident would proudly arrive with a linen-covered tray laden with tea and buns.' The ladies wore colourful clothing, they brought him their small troubles, or bits of gossip- Do you like my hair, Doctor?' There was rarely anything wrong with them, medically: 'Overall, my experience with the Magdalene was a happy and gratifying one.' And as for death certs, he often had to tell people about death certs, we can assume he was worn out telling them. The women Dr Coughlan saw in 1984 were among the last Magdalenes. It is possible they were institutionalised, though he sees that damage as a kind of sweetness. It is possible - though it is really not possible—that it wasn't all that bad and, besides, it is fine now.

ENRIGHT 2015

In presenting these narratives from key informants, I do not wish to suggest that they necessarily represent the factual views of these people, or that they had no idea of the abusive nature of the laundries. Instead, I wish to demonstrate the ease with which wider Irish society was able to erase and ignore the violence suffered by women in Magdalene institutions, reframing them in penitential or reformatory terms, as a result of ingrained ideas around morality and 
productive work. The power of these moral associations is so strong that even those who came into direct contact with women doing this hard, forced manual labour for no money were able to praise the 'jovial' attitude of the women, their sweet natures and above all, their strong work ethic. In doing so, they show the desire to see work as a productive, beneficial force which possesses a strong moral value. They are witnessing the work as such because it allows them to avoid the violent realities of the laundries, conceptualising them as places of labour, rather than sites of trauma.

\section{7}

\section{Conclusion}

Work in the form we know it today is an invention of modernity (Gorz 1989, 13). It functions as a social value - through hard work and productivity people are transformed into 'workers', and value is ascribed to their bodies in terms of how they contribute to society as a whole. Bodies which may lack this capacity for productivity - people with disabilities, old people, people with mental health conditions-have frequently been conceptualized as possessing less social value, because they are perceived to contribute less. Even now, the UK and many other countries require people who wish to claim benefits to make efforts at productivity. They must demonstrate that they wish to be useful, be valuable, get a job-otherwise they receive sanctions, penalties for a failure to perform the desire for productivity. Patricia Dervan sharply illustrates the consequences of this focus on productivity for Magdalene laundry survivors. Speaking of her sister-in-law who had been in a laundry, she says that there was:

No value being put on her life, you know, in our society we tend to value people in terms of their contribution to society through their work, and we tend to reward that work with payment, but in her case there was no value put on herself.

MAgohp/o6, Patricia Dervan: tape 2, 32:38

Patricia's words are echoed by Just, who writes that:

Modern power deals with living beings, their productivity, and their usefulness to the economic welfare of the population as a whole. In modernity, the lives of everyone, not just those concerned with financial gain, are determined by work and economic valuation.

JUST 2017,16 
The laundries occupied a certain space within this discourse of productivity —as well as having religious moral symbolism, the work could be conceptualised as good and valuable for society. These women were portrayed as bad, dirty girls - women who had transgressed the social and moral norms of twentieth century Ireland by making themselves in some way 'too visible'. They were contained in a physical space for their own good, and for the good of society, keeping their contagious immorality away from the general public (Crowley and Kitchen 2008). To redeem themselves in the eyes of society, and cleanse their souls, they needed to do the physical work of cleaning laundry-good, productive women's work, making them valuable members of society who were contributing to the greater good.

This article has highlighted how the nature of the work being done by those incarcerated made a difference to the ways in which people perceived the institutions, drawing on interviews taken with survivors and key informants, as well as state documents and resources. I have argued that modernity's obsession with productivity, and the moral meanings imbued within this, allowed the laundries to be viewed as sites of labour rather than sites of violence and trauma. However, as the testimony from the oral histories makes evident, these institutions were deeply violent spaces, in both a psychological and physical sense. The physical trauma of the laundries is written on the bodies of the survivors, in the long-term physical health conditions many of them now suffer from. The work they were forced to do was violence-painful, damaging and with serious consequences. From the structure of the day to the physical limitations of their movements, the whole experience of the laundry was designed to discipline the body, transforming the women from unruly, dangerous subjects to docile penitents. The forced labour they endured should be understood as another disciplinary process used to achieve this, rather than a useful and productive form of work.

\section{Acknowledgments}

I wish to begin by extending my thanks and gratitude to all those who shared their narratives in the 'Magdalene Institutions: Recording an Archival and Oral History' project, particularly those who spent time in an institution. Thank you for allowing me to read your words and hear your voices. This was a Government of Ireland Collaborative Research Project, funded by the Irish Research Council; I am particularly grateful to Dr Katherine O'Donnell and the whole research team for allowing me to use the archive for my own work. Some of these interviews are available to listen to and read at: http://jfmresearch.com/ 
home/oralhistoryproject/. This work was generously funded and made possible by an Arts and Humanities Research Council grant.

\section{References}

Andersen, Thomas Barnbeck; Bentzen, Jeanet; Dalgaard, Carl-Johan \& Sharp, Paul. 2017. 'Pre-reformation Roots of the Protestant Ethic', The Economic Journal 127:604, 17561793 .

Anthias, Floya. and Yuval-Davis, Nira. 1989. 'Introduction' in Nira Yuval-Davis and Floya Anthias, (eds.), Women—Nation—State, Basingstoke: Macmillan Press, 1-15.

Aylward, Sean. 2011. Sean Answers Questions from UnCAT Committee Members on Human Rights Violations in the Magdalene Laundries [Online]. Available at:https:// www.youtube.com/watch?v=tSrDbeO 5 wYs-[accessed 10/7/17].

Brownmiller, Susan. 1975. Against Our Will: Men, Women and Rape, New York: Simon and Schuster.

Clough, Myriam. 2017. Shame, the Church and the Regulation of Female Sexuality, Oxford: Routledge.

Crowley, Una and Kitchin, Rob. 20o8. 'Producing 'decent girls': governmentality and the moral geographies of sexual conduct in Ireland (1922-1937)', Gender, Place \& Culture $15: 4,355^{-}-372$.

DeSante, Christopher. 2013. 'Working Twice as Hard to Get Half as Far: Race, Work Ethic, and America's Deserving Poor', American Journal of Political Science 57:2, 342-356.

Duff, Antony. 2003. 'Penance, Punishment and the Limits of Community', Punishment \& Society, 5:3, 295-312.

Earner-Byrne, Lindsey. 2007. Mother and Child: Maternity and Child Welfare in Dublin, 1922-1960, Manchester: Manchester University Press.

Enright, Anne. 2015. 'Antigone in Galway'. London Review of Books 37:4, 11-14.

Enright, Máiréad and Sinéad Ring. 2020. 'State Legal Responses to Historical Institutional Abuse: Shame, Sovereignty, and Epistemic Injustice', Éire-Ireland 55:1, 6899 .

Fischer, Clara. 2017. Revealing Ireland's “Proper” Heart: Apology, Shame, Nation. Hypatia, 32:4, 751-767.

Finnigan, Frances. 2001. Do Penance or Perish: Magdalen Asylums in Ireland, Oxford: Oxford University Press.

Foucault, Michel. 1980. The History of Sexuality: Volume I: An Introduction, Trans. R. Hurley, New York: Vintage.

Frazer, Elizabeth and Hutchings, Kimberley. 2020. 'The feminist politics of naming violence', Feminist Theory, 21:2, 199-216.

Gorz, André. 1989. Critique of Economic Reason, London: Verso. 
Gott, Chloë. 2022. Experience, Identity \& Epistemic Injustice Within Ireland's Magdalene Laundries, London: Bloomsbury.

Glucklich, Ariel. 2001. Sacred Pain: Hurting the Body for the Sake of the Soul, Oxford: Oxford University Press.

Glynn, Evelyn. 'Oral History of John Kennedy', In O’Donnell, K., S. Pembroke and C. McGettrick. 2013. Magdalene Institutions: Recording an Oral and Archival History. Government of Ireland Collaborative Research Project, Irish Research Council, pp. 1-30.

Halasz, Judith. 2012. 'The Ethics of Work: Productivity, the Work Ethic, and Bohemian Self-Determination', Journal of Humanities and Social Sciences 2:4, 209-222.

Höpfl, Harro. 2007. 'A Catholic Work Ethic?', Journal of Management, Spirituality \& Religion 4:4, 398-417.

Irish Human Rights and Equality Commission. 2015. 'Submission to UN Human Rights Committee on Ireland's One-Year Follow-up Report to its Fourth Periodic Review under ICCPR', accessed 22nd February 2021, https://tbinternet.ohchr.org/Treaties/ CCPR/Shared\%2oDocuments/IRL/INT_CCPR_NGS_IRL_218o2_E.pdf.

John Paul II, 1981, Laborem Exercens, accessed 22nd February 2021, http://www.vatican .va/content/john-paul-ii/en/encyclicals/documents/hf_jp-ii_enc_14091981_labore m-exercens.html.

Just, Daniel. 2017. 'The Invention of Work in Modernity: Hegel, Marx, and Weber', Journal of Historical Sociology 30, 435-456.

Justice for Magdalenes Research. 2015. 'NGO Submission to the UN Committee on the Elimination of Discrimination Against Women in respect of Ireland' [online], accessed 2nd March 2019, https://tbinternet.ohchr.org/Treaties/CEDAW/Shared\% 2oDocuments/IRL/INT_CEDAW_NGO_IRL_2186o_E.pdf.

Kandiyoti, Deniz. 1991. 'Identity and its Discontents: Women and the Nation', American Journal of Political Science, 20(3), 429-443.

Kelly, Liz. 1988. Surviving Sexual Violence, Cambridge: Polity Press.

Luddy, Maria. 2007. Prostitution and Irish Society: 1800 to 1940, Manchester: Manchester University Press.

Luddy, Maria. 1995. Women and Philanthropy in Nineteenth-Century Ireland, Cambridge: Cambridge University Press.

Lundgren, Eva. 1998. 'The Hand That Strikes and Comforts: Gender Construction and the Tension Between Body and Symbol' in Rebecca Emerson Dobash and Russell P. Dobash (eds.), Rethinking Violence Against Women. Thousand Oaks, CA: SAGE Publications Inc, 169-198.

McAleese, Martin. 2013. 'Report of the Inter-Departmental Committee to establish the facts of State involvement with the Magdalen Laundries', Dublin: Dept of Justice and Equality, accessed 2nd October 2017, http://www.justice.ie/en/JELR/Pages/ MagdalenRpt2o13. 
McClintock, Anne. 1997 “"No Longer in a Future Heaven”: Gender, Race and Nationalism', in Anne McClintock, Aamir Mufti and Ella Shohat, (eds.), Dangerous Liaisons: Gender, Nation and Postcolonial Perspectives, Minneapolis: University of Minnesota Press, pp. 89-112.

McGettrick, Claire., O'Donnell, Katherine., O'Rourke, Maeve., Smith, James M., Steed, Mari. 2021. Ireland and the Magdalene Laundries: A Campaign for Justice, London: Bloomsbury.

McGettrick, Claire, and Justice for Magdalenes Research. 2015. 'Death, Institutionalisation \& Duration of Stay: A critique of Chapter 16 of the Report of the InterDepartmental Committee to establish the facts of State involvement with the Magdalen Laundries and Related Issues', accessed 22nd February 2021, http://jfmresearch .com/wp-content/uploads/2017/o3/JFMR_Critique_190215.pdf.

Moore, Barrington. 1998. Moral Aspects of Economic Growth, Ithaca: Cornell University Press.

O’Donnell, Katherine; Pembroke, Sinead and McGettrick, Claire. 2013. 'Magdalene Institutions: Recording an Oral and Archival History'. Government of Ireland Collaborative Research Project, Irish Research Council, http://www.magdaleneoralhistory .com and http://jfmresearch.com/home/oralhistoryproject/.

O'Mahoney, Jennifer. 2018. 'Advocacy and the Magdalene Laundries: Towards a Psychology of Social Change', Qualitative Research in Psychology 15:4: 456-471.

O'Rourke, Maeve, and Justice for Magdalenes Research. 2017. 'NGo Submission to the UN Committee Against Torture in respect of IRELAND (for the session) July 2017', accessed 22nd February 2021, http://jfmresearch.com/wp-content/uploads/ 2017/o7/JFMR-report-to-CAT-for-the-session-2017-Main-Report.pdf.

Orwell, George. 2001. The Road to Wigan Pier, London: Penguin.

Phillips, Melanie. 2011. 'It's not just absent fathers, Mr Cameron. Family breakdown is driven by single mothers on benefits', The Daily Mail, 20 June, accessed 23rd July 2020, https://www.dailymail.co.uk/debate/article-2005677/Family-breakdown -driven-single-mothers-benefits-absent-fathers.html.

Sennett, Richard. 1998. The Corrosion of Character: The Personal Consequences of Work in the New Capitalism, New York: Norton.

Serisier, Tanya. 2018. Speaking Out: Feminism, Rape and Narrative Politics, London: Palgrave Macmillan.

Skeggs, Beverley. 1997. Formations of Gender and Class: Becoming Respectable, London: SAGE Publications.

Smith, James. 2007. Ireland's Magdalen Laundries and the Nation's Architecture of Containment, Manchester: Manchester University Press.

Spirenburg, Pieter. 2013. Violence and Punishment: Civilizing the Body Through Time, Cambridge, Polity Press.

Thane, Pat and Evans, Tanya. 2013. Sinners? Scroungers? Saints?: Unmarried Motherhood in Twentieth-Century England, Oxford: Oxford University Press. 
Valentine, Gill and Harris, Catherine. 2014. 'Strivers vs skivers: Class prejudice and the demonisation of dependency in everyday life', Geoforum 53, 84-92.

Weber, Max. 2001 [1930]. The Protestant Ethic and the Spirit of Capitalism, New York, NY: Routledge.

Yuval-Davis, Nira. 1997. Gender and Nation, London: Sage Publications.

'Rise and rise of the welfare mother'. 1996. The Irish Times, o6 March, accessed 2nd July 2020, https://www.irishtimes.com/culture/rise-and-rise-of-the-welfare-mother -1.33405 . 